\title{
INTERACTION OF LARGE PILES WITH A MULTILAYER SOIL MASS, TAKING INTO ACCOUNT HARDENING AND SOFTENING
}

\author{
Zaven G. Ter-Martirosyan, Armen Z. Ter-Martirosyan, Aleksandr S. Akuletsky \\ National Research Moscow State University of Civil Engineering, Moscow, RUSSIA
}

\begin{abstract}
This article discusses the formulation and solution of the problem of the interaction of a long pile with the surrounding multilayer and underlying soils, taking into account the rheological properties of the surrounding soil mass. The creep process is considered taking into account hardening and softening. The problem was considered in a linear setting. The solution is presented by analytical method. To describe the creep process, the rheological parameters of hardening and softening were used. An expression is obtained for finding the reduced shear modulus for a multilayer soil mass. A dependence is obtained for determining the force on the pile heel on time, taking into account the rheological parameters of hardening and softening. Analytical solutions in the article are supported by a graphical part. The graphs of the dependence of the settlement of the pile, the force on the heel of the pile cutting through alternating layers, on time for various parameters of viscosity, as well as for variable parameters of hardening and softening are given. The solutions obtained can be used for preliminary determination of the movement of long piles with the surrounding multilayer and underlying soils.
\end{abstract}

Keywords: pile interaction, multilayer and underlying soils, analytical method, reduced modulus, rheological properties, settlement rate, hardening factor, softening factor.

\section{ВЗАИМОДЕЙСТВИЕ СВАИ БОЛЬШОЙ ДЛИНЫ С МНОГО- СЛОЙНЫМ МАССИВОМ ГРУНТА С УЧЕТОМ УПРОЧНЕНИЯ И РАЗУПРОЧНЕНИЯ}

\author{
3.Г. Тер-Мартиросян, А.3. Тер-Мартиросян А.С. Акулецкий
}

Национальный исследовательский Московский государственный строительный университет, г. Москва, РОССИЯ

\begin{abstract}
Аннотация: В данной статье рассмотрена постановка и решение задачи о взаимодействии сваи большой длины с окружающим многослойным и подстилающим грунтами с учетом реологических свойств окружающего массива грунта. Процесс ползучести рассматривается с учетом упрочнения и разупрочнения. Задача рассматривалась в линейной постановке. Решение изложено аналитическим методом. Для описания процесса ползучести использовались реологические параметры упрочнения и разупрочнения. Получено выражение для нахождения приведенного модуля сдвига для многослойного массива грунта. Получена зависимость для определения усилия на пяту сваи от времени с учетом реологических параметров упрочнения и разупрочнения. Аналитические решения в статье подкреплены графической частью. Приведены графики зависимости осадки сваи, усилия на пяту сваи, прорезающей чередующиеся слои, от времени при различных параметрах вязкости, а также при переменных параметрах упрочнения и разупрочнения. Полученные решения могут быть использованы для предварительного определения перемещения сваи большой длины с окружающим многослойным и подстилающим грунтами.
\end{abstract}

Ключевые слова: взаимодействие сваи, многослойный и подстилающий грунты, аналитический метод, приведенный модуль, реологические свойства, скорость осадки, коэффициент упрочнения,

коэффициент разупрочнения. 


\section{INTRODUCTION}

Construction sites are characterized mainly by difficult engineering and geological conditions, represented by the presence of several layers at the base, including weak clayey water-saturated soils. Under these conditions, as a rule, it is used: soil consolidation [1-5], soil reinforcement [67], significant deepening of the underground part of buildings, etc. But the pile foundation is considered as the main type of foundation on such sites [8-14]. When the basement of weak clayey soils occurs, the settlement of the building can continue for a long period of time. There are cases when the settlements of buildings and structures did not subside for several decades. The most famous example of the Leaning Tower of Pisa, the slope of which developed over several centuries. In the design of foundations on such soils, the forecast of settlement over time is of great importance. The strength and stability of structures will depend both on the rate of development of the settlement over time and on the final settlement of the structure. Therefore, the approach to the description of the process of foundation settlement should be considered as rheological [15-22]. It is known that when a long pile interacts with the surrounding multilayer and underlying soils, a complex inhomogeneous stress-strain state arises. In this paper, we consider the problem of the interaction of a long pile with a multilayer soil massif in a linear formulation, which has rheological properties, as well as the problem of determining the reduced shear modulus for a soil massif.

Studies of the operation of a long pile show that the effect of the length of the pile on the surrounding soil mass extends to a distance of no more than 6-7 pile diameters, and of the same order in depth under its lower end [23]. The distance between the piles less than six diameters ensures the displacement of the pile and the soil in the inter-pile space at the same time. These studies allow us to consider the displacement of the pile foundation and soil as a single massif, and also allow the problem of the interaction of a long pile with a soil massif to be considered as the problem of the interaction of a pile with a soil massif of limited dimensions in the form of a cylinder with a diameter $2 b$ and height $L>l$, where $l$ is the length of the pile (Fig. 1).



\section{Figure 1. Design model of interaction of pile} with multilayer soil column.

\section{MATERIALS AND METHODS}

Analysis of the stress-strain state of soils around the pile and under its end showed that shear deformations prevail when the pile interacts with the soil, volumetric deformations can be ignored [24]. The solution to the problem will be considered for a round pile. We also assume that the stiffness of the pile significantly exceeds the stiffness of the soil.

$$
E_{c в .}>E_{2 p .}
$$

Let us write down the equilibrium equation for the considered case (Fig. 1):

$$
N=T+R
$$

where

$$
N=\pi a^{2} p_{1}
$$




$$
\begin{aligned}
& T=2 \pi a l \tau \\
& R=\pi a^{2} p_{2} .
\end{aligned}
$$

Substituting equations (2), (3), (4) into equation (1), we obtain expressions for $\tau$ :

$$
\tau=\left(p_{1}-p_{2}\right) \frac{a}{2 l}
$$

Since $E_{c b .} \gg E_{z p}$. the settlement of the pile of each layer under consideration is equal, i.e.

$$
S_{1}=S_{2}=S_{i}=S
$$

where $S_{i}$ is a pile settlement for $i$-for layer; $S$ is a total pile settlement.

Shear deformation of the elementary soil layer around the pile can be determined by the following relationship:

$$
\gamma_{i}(r)=-\frac{\tau_{i}(r)}{G_{i}}
$$

where $G_{i}$ is shear modulus for $i$-th layer; $i=1$, $2, \ldots, n$ is layer number.

Based on condition (6), we can write an expression for the tangential stresses of the i-th layer:

$$
\tau_{i}=\frac{\tau}{G} G_{i},
$$

where $G$ is a reduced shear modulus for multilayer soil mass.

Based on the condition for the distribution of shear stresses along the length of the pile, we obtain:

$$
\tau l=\tau_{1} l_{1}+\tau_{2} l_{2}+\tau_{i} l_{i}
$$

Considering (9) and (8) together, we obtain an expression for determining the reduced shear modulus for a multilayer soil mass:

$$
G=\frac{l_{1} G_{1}+l_{2} G_{2}+l_{i} G_{i}}{l}
$$

where $l$ is a pile length; $i=1,2, \ldots, n$ is layer number.

Let us write the dependence for the rate of change in shear deformation around the pile, taking into account the rheological properties of the surrounding soil mass:

$$
\dot{\gamma}=-\frac{\dot{\tau}_{\alpha}}{G}+\frac{\tau_{\alpha}}{\eta(t)}
$$

where $\tau_{\alpha}$ is shear stress rate; $\tau_{\alpha}=T / 2 \pi a l$; $\eta(t)$ - weighted average viscosity index.

Because the forces transferred to the pile are constant $\left(p_{1}=\right.$ const $)$, the pressure rate at the pile head does not change $\left(\dot{p}_{1}=0\right)$. Based on this, we determine the rate of change in shear stresses:

$$
\dot{\tau}_{\alpha}=-\dot{p}_{2} \frac{a}{2 l}
$$

The rate of settlement of the pile from the action of shear stresses on the lateral surface, taking into account the elastic-viscous characteristics of the surrounding soil mass:

$$
\dot{V}_{T}=\frac{a \tau_{\alpha}}{\eta(t)} \ln \left(\frac{b}{a}\right)+\frac{a \dot{\tau}_{\alpha}}{G} \ln \left(\frac{b}{a}\right),
$$

where $G$ was obtained from (10).

Let us determine the rate of settlement of the pile due to the deformation of the soil under the lower end of the pile, assuming that the pile acts as a flat round stamp. The equation is:

$$
\dot{V}_{R}=\dot{p}_{2} \frac{\pi a\left(1-v_{0}\right) K}{4 G_{0}},
$$

where $\dot{p}_{2}$ is pressure rate under the pile heel; $v_{0}$ and $G_{0}$ is deformation parameters of the soil 
under the lower end of the pile; $K \leq 1-$ coefficient taking into account the depth of application of the load on the pile heel.

Based on the fact that $E_{c \varepsilon}$. $>E_{2 p \text {. }}$ the rate of settlement from forces on the lateral surface is equal to the rate of settlement from the action of forces at the level of the lower end of the pile. Equating (13) and (14), as well as taking into account (5) and (12), we obtain:

$$
\begin{aligned}
& \left(p_{1}-p_{2}\right) \frac{a^{2}}{2 \ln (t)} \ln \left(\frac{b}{a}\right)-\dot{p}_{2} \frac{a^{2}}{2 l G} \ln \left(\frac{b}{a}\right)= \\
& =\dot{p}_{2} \frac{\pi a\left(1-v_{0}\right) K}{4 G_{0}}
\end{aligned}
$$

After performing certain transformations, we get the following differential equation:

$$
\dot{p}_{2}+p_{2} \frac{1}{\eta(t) A}=\frac{p_{1}}{\eta(t) A}
$$

где

$$
A=\frac{\pi\left(1-v_{0}\right) K l}{2 G_{0} a \ln \left(\frac{b}{a}\right)}+\frac{1}{G}
$$

The general solution of the differential equation (16) is found by the formula [25]:

$$
p_{2}(t)=e^{-\int \frac{d t}{\eta(t) A}}\left(\int \frac{p_{1}}{\eta(t) A} e^{\int \frac{d t}{\eta(t) A}} d t+C\right) .
$$

To describe the creep process, we use the rheological parameters of hardening and softening. Let us consider the solution of Eq. (18) taking into account hardening, when $\eta(t)=\eta_{0} e^{\alpha t}$. In this case:

$$
p_{2}(t)=e^{-\int \frac{d t}{\eta_{0} e^{\alpha t} A}}\left(\int \frac{p_{1}}{\eta_{0} e^{\alpha t} A} \cdot e^{\int \frac{d t}{\eta_{0} e^{\alpha t} A}} d t+C\right),
$$

where $\eta_{0}$ is initial coefficient of soil viscosity; $\alpha$ is soil hardening factor.

$$
\begin{aligned}
& p_{2}(t)=e^{\frac{e^{-\alpha t}}{\alpha \eta_{0} A}}\left(\int \frac{p_{1}}{\eta_{0} e^{\alpha t} A} e^{-\frac{e^{-\alpha t}}{\alpha \eta_{0} A}} d t+C\right)= \\
& =e^{\frac{e^{-\alpha t}}{\alpha \eta_{0} A}}\left(p_{1} e^{-\frac{e^{-\alpha t}}{\alpha \eta_{0} A}}+C\right)=p_{1}+C e^{\frac{e^{-\alpha t}}{\alpha \eta_{0} A}}
\end{aligned}
$$

Integration constant $C$ is determined from the initial condition at $t=0$. Then:

$$
C=\left(p_{2}(0)-p_{1}\right) / e^{\frac{1}{A \alpha \eta_{0}}} .
$$

Finally, we obtain:

$$
p_{2}(t)=p_{1}+\left(p_{2}(0)-p_{1}\right) e^{\frac{e^{-\alpha t}-1}{A \alpha \eta_{0}}}
$$

The settlement of the pile at a certain point in time $t$ can be determined by the formula:

$$
V_{R}(t)=p_{2}(t) \frac{\pi a\left(1-v_{0}\right) K}{4 G_{0}},
$$

where $p_{2}(t)$ we find by the formula (22).

Consider the solution to Eqs. (22) and (23) with the initial condition $p_{2}(0)=0$ with variable values $\quad \eta_{1}=1 \cdot 10^{11} \Pi, \quad \eta_{2}=5 \cdot 10^{11} \Pi$, $\eta_{3}=1 \cdot 10^{12} \Pi, \quad \eta_{4}=5 \cdot 10^{12} \Pi, \quad$ а $\quad$ также $\alpha=0.05 ; l=30 \mathrm{~m} ; a=0.5 \mathrm{~m} ; b=6.5 \cdot a ; E_{1}=$ $30 \mathrm{MPa}, E_{2}=10 \mathrm{MPa}, E_{3}=25 \mathrm{MPa}, E_{0}=50$ $M P a ; v_{1}=v_{2}=v_{3}=v_{0}=0.35 ; K=0.7$ 


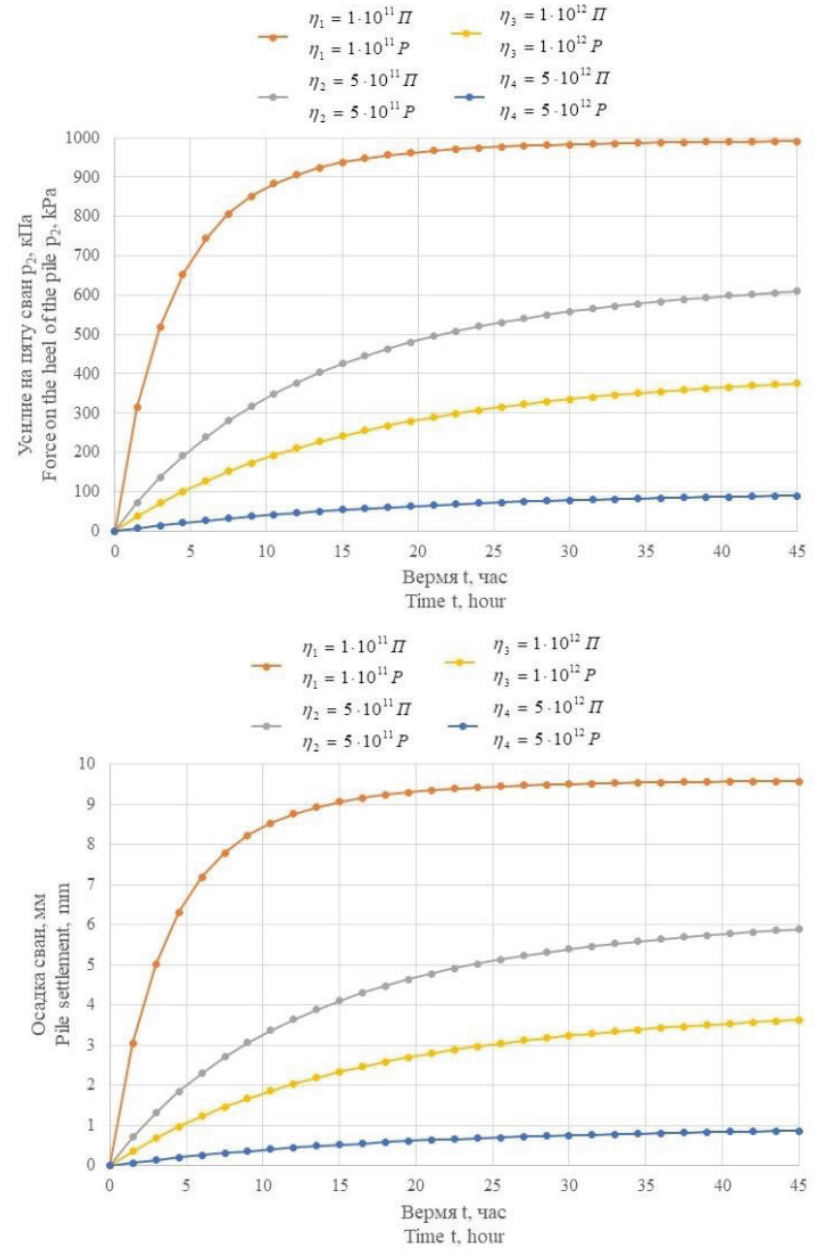

Figure 2. Dependency graphs $p_{2}(t)$ (up) and $V_{R}(t)$ (down) at various parameters of the viscosity of the surrounding soil.

Consider the solution to Eqs. (22) and (23) for variable values $\alpha_{1}=0.10, \alpha_{2}=0.15, \alpha_{3}=0.20$ , $\alpha_{4}=0.25$, as well as $\eta_{1}=1 \cdot 10^{12} \Pi ; l=30 \mathrm{~m}$; $a=0.5 \mathrm{~m} ; b=6.5 \cdot a ; E_{1}=30 \mathrm{MPa}, E_{2}=10 \mathrm{MPa}$, $E_{3}=25 \mathrm{MPa}, E_{0}=50 \mathrm{MPa}$; $v_{1}=v_{2}=v_{3}=v_{0}=0.35 ; K=0.7$

Let us consider the solution of Eq. (18) taking into account the softening, when $\eta(t)=\eta_{0} e^{-\beta t}$. In this case:

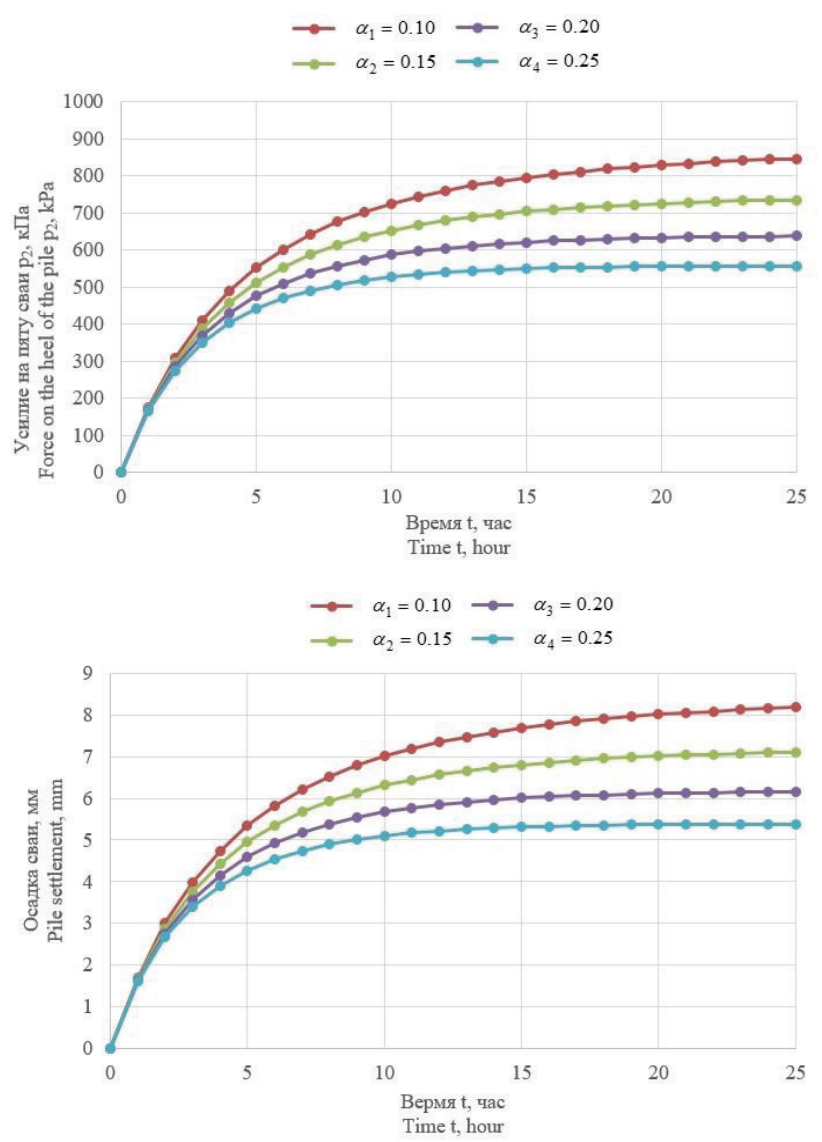

Figure 2. Dependency graphs $p_{2}(t)$ (up) and $V_{R}(t)$ (down) at different values of the hardening coefficient

$p_{2}(t)=e^{-\int \frac{d t}{\eta_{0} e^{-\beta t} A}}\left(\int \frac{p_{1}}{\eta_{0} e^{-\beta t} A} \cdot e^{\int \frac{d t}{\eta_{0} e^{-\beta t} A}} d t+C\right)$

where $\eta_{0}$ is initial coefficient of soil viscosity; $\beta$ is soil softening factor.

$p_{2}(t)=e^{-\frac{2 e^{\beta t}}{\eta_{0} A}}\left(p_{1} e^{\frac{2 e^{\beta t}}{\eta_{0} A}}+C\right)=p_{1}+C e^{-\frac{2 e^{\beta t}}{\eta_{0} A}}$.

Integration constant $\mathrm{C}$ is determined from the initial condition at. Then: 
Interaction of Large Piles with a Multilayer Soil Mass, Taking Into Account Hardening and Softening

$$
C=\left(p_{2}(0)-p_{1}\right) / e^{-\frac{2}{\eta_{0} A}}
$$

Finally, we obtain:

$$
p_{2}(t)=p_{1}+\left(p_{2}(0)-p_{1}\right) e^{\frac{-2\left(e^{\beta t}-1\right)}{A \eta_{0}}}
$$
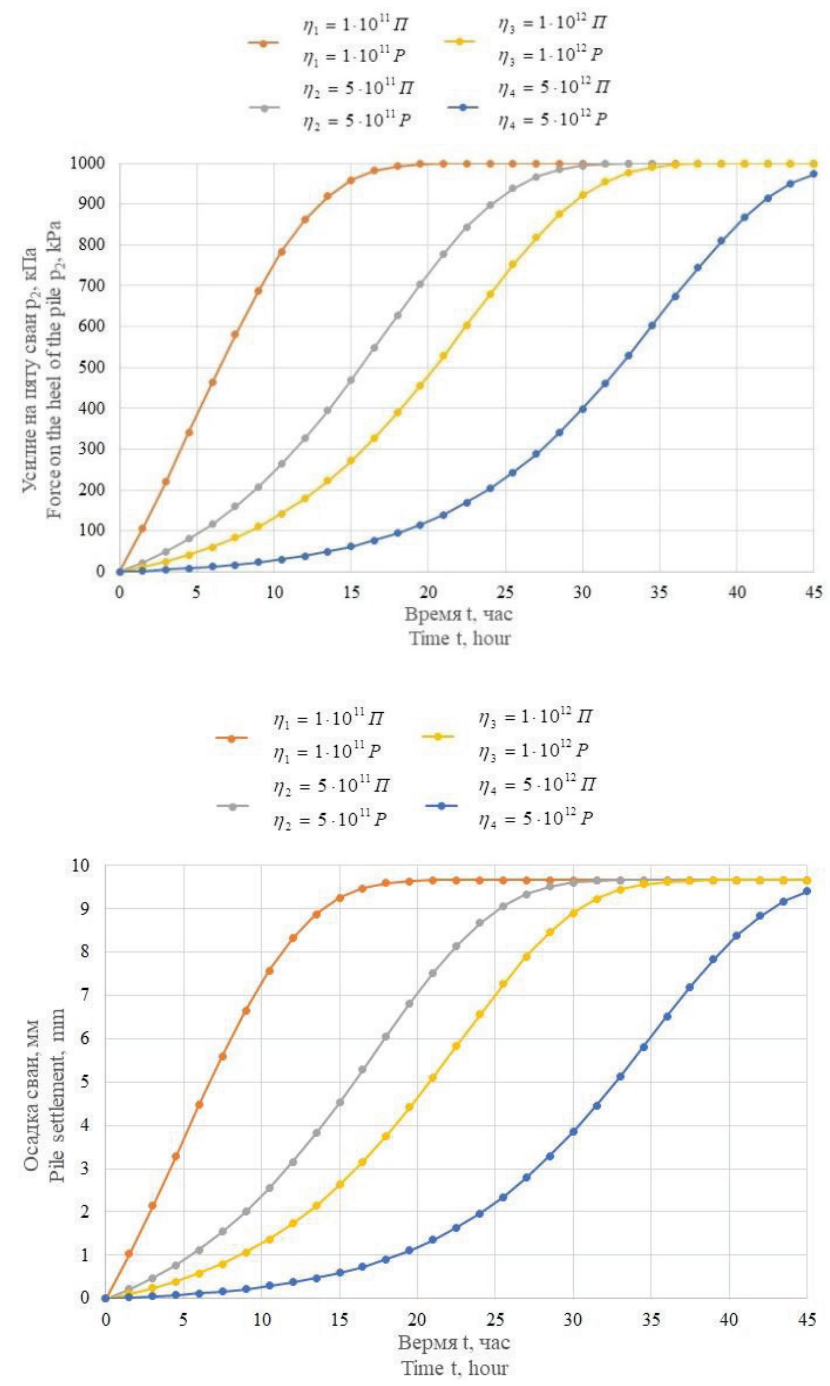

Figure 4. Dependency graphs $p_{2}(t)$ (up) and $V_{R}(t)$ (down) at various parameters of the viscosity of the surrounding soil
Consider the solution to Eqs. (27) and (23) with the initial condition $p_{2}(0)=0$ with variable values $\quad \eta_{1}=1 \cdot 10^{11} \Pi, \quad \eta_{2}=5 \cdot 10^{11} \Pi$, $\eta_{3}=1 \cdot 10^{12} \Pi, \quad \eta_{4}=5 \cdot 10^{12} \Pi, \quad$ as well as $\beta=0.05 ; l=30 \mathrm{~m} ; a=0.5 \mathrm{~m} ; b=6.5 \cdot a ; E_{1}=30$ $\mathrm{MPa}, E_{2}=10 \mathrm{MPa}, E_{3}=25 \mathrm{MPa}, E_{0}=50 \mathrm{MPa}$; $v_{1}=v_{2}=v_{3}=v_{0}=0.35 ; K=0.7$

Consider the solution to Eqs. (27) and (23) for variable values $\beta_{1}=0.10, \beta_{2}=0.15, \beta_{3}=0.20$ , $\beta_{4}=0.25$, as well as $\eta_{1}=1 \cdot 10^{12} \Pi ; l=30 \mathrm{~m}$; $a=0.5 \mathrm{~m} ; b=6.5 \cdot a ; E_{1}=30 \mathrm{MPa}, E_{2}=10 \mathrm{MPa}$, $E_{3}=25 \mathrm{MPa}, E_{0}=50 \mathrm{MPa}$; $v_{1}=v_{2}=v_{3}=v_{0}=0.35 ; K=0.7$

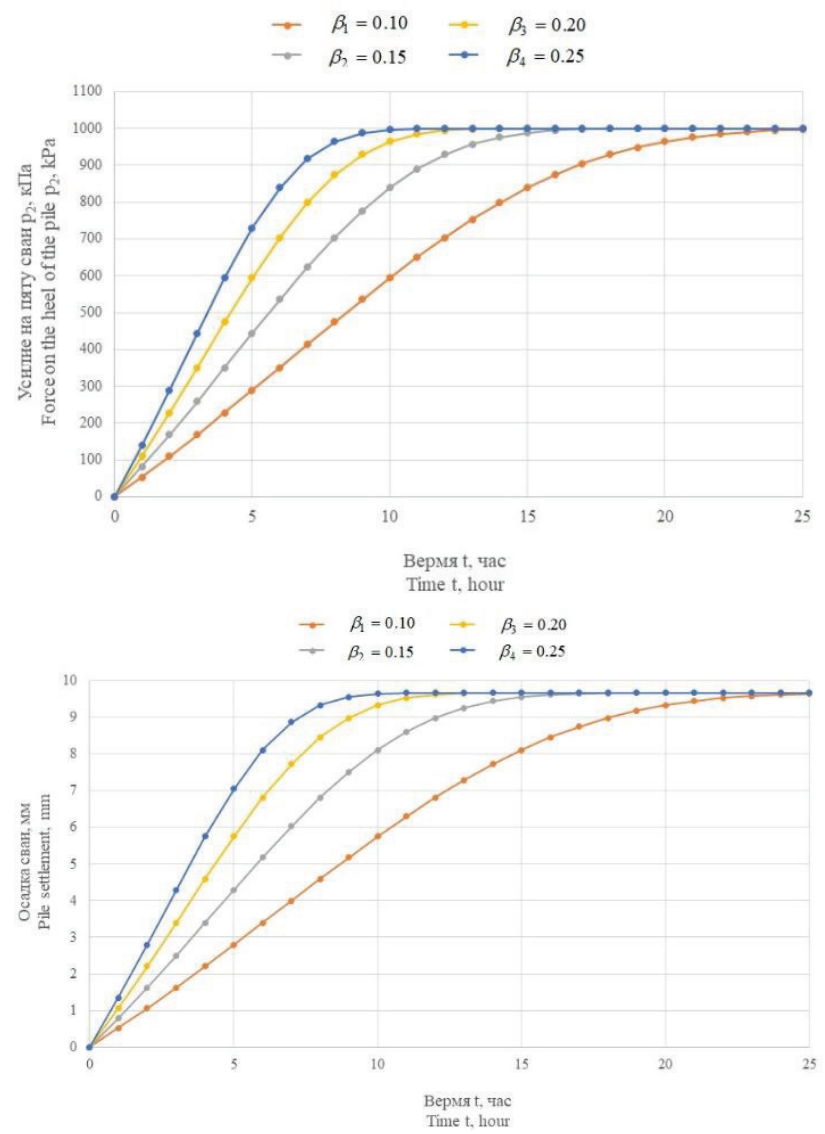

Figure 5. Dependency graphs $p_{2}(t)$ (up) and $V_{R}(t)$ (down) at different values of the hardening coefficient 


\section{RESULTS}

Analysis of the obtained dependences shows that over time, the stress under the pile base and the pile settlement change at different rates and tend to a constant value (for $t \rightarrow \infty, p_{2}(t) \rightarrow p_{2 \infty}$ $=$ const, $V_{R}(t) \rightarrow V_{R \infty}=$ const $)$. Therefore, based on condition (5), the shear stresses on the lateral surface of the pile decrease with time. The obtained dependencies make it possible to predict the development of precipitation in time. According to the data obtained, with an increase in the viscosity coefficient, a decrease in the rate of stress change under the pile base, as well as pile settlement, is observed. According to the obtained dependences (Fig. 3, 5), with an increase in the hardening coefficient, the final pressure under the pile base and the pile settlement decreases. Taking into account the rheological coefficient of softening, a complex nature of the time redistribution of efforts between the head and the fifth pile is observed.

\section{CONCLUSION AND DISCUSSION}

When the pile interacts with the surrounding multilayer soil massif, which has elastic-viscous characteristics, a complex stress-strain state arises, in which the stress under the pile base changes over time. According to the obtained dependencies, over time, the stresses on the heel of the pile increase, while the shear stresses decrease. The obtained dependencies allow predicting the development of pile settlement in time. The rheological properties of a multilayer soil massif have a significant impact on the nature of the redistribution of forces on the pile between the lateral surface and the lower end. The results obtained indicate that the formation of stress-strain state around the pile in time depends on the form of the function of changing the viscosity parameters. Analysis of the graphs obtained shows that the time of stabilization of the sediment, as well as the time of stabilization of the pressure under the heel of the pile, significantly depends on the rheological coefficients of hardening and softening.

\section{REFERENCES}

1. Abelev M.YU., Abelev K.M. Geotekhnicheskiye issledovaniya ploshchadok stroitel'stva, slozhennykh slabymi vodonasyshchennymi glinistymi gruntami [Geotechnical studies of construction sites, composed of weak water-saturated clayey soils] // Geotekhnika. 2010. No 6. Pp. 30-33.

2. Ibragimov M.N., Semkin V.V. Zakrepleniye gruntov in"yektsiyey tsementnykh rastvorov [Consolidation of soils by injection of cement mortars]. Moscow, 2012, 256 p.

3. Broyd I.I. Struynaya geotekhnologiya [Jet geotechnology]. Moscow: ASV Publishing. 2004. 448 p.

4. Malinin A.G. Struynaya tsementatsiya gruntov [Jet grouting of soils]. URL: https://jetgrouting.info/wp-content/uploads/2019/02/ JET-GROUTING_book_Malinin_AG.pdf

5. GarassimoA.DesignProcedures forJet-Grouting // Seminar onjet grouting. Singapore, 1997.

6. Karaulov A.M. Prakticheskiy metod rascheta vertikal'no armirovannogo osnovaniya lentochnykh i otdel'nostoyashchikh fundamentov transportnykh sooruzheniy [A practical method for calculating a vertically reinforced base of tape and freestanding foundations of transport structures] // Vestnik TGASU. 2012. No 2. Pp. 183-190.

7. Nuzhdin M.L. Eksperimental'nyye issledovaniya usileniya gruntovogo osnovaniya svaynykh fundamentov armirovaniyem zhestkimi vklyucheniyami [Experimental studies of strengthening the soil base of pile foundations by reinforcement with rigid inclusions] // Vestnik PNIPU. Stroitel'stvo i arkhitektura. 2019. Vol. 10, No 3. Pp. 5-15. DOI: 10.15593/2224-9826/2019.3.01.

8. Ter-MartirosyanA.Z.,LeDykAn, Manukyan A.V. Vliyaniye razzhizheniya gruntov na raschetnuyu nesushchuyu sposobnost' svay [Influence of soil liquefaction on the design bearing capacity of piles] // Vestnik MGSU. 2020. Vol. 15. Iss. 5. Pp. 655-664. DOI: 10.22227/1997-0935.2020.5.655-664. 
9. Bartolomey A.A., Omel'chak I.M., Yushkov B.S. Prognoz osadok svaynykh fundamentov [Forecast of the settlement of pile foundations]. Moscow: Stroyizdat. 1994. 384 p.

10. Building Code ofRFSP24.13330.2011 Svaynyye fundamenty. Aktualizirovannaya redaktsiya SNiP 2.02.03-85 [Pile foundations. Updated edition of SNiP 2.02.03-85]. Moscow, 2011.

11. Wei Dong Guo. Theory and Practice of Pile Foundations. CRC Press, 2019. 576 p.

12. Shamsher Prakash, Hari D. Sharma. Pile foundation in engineering practice. John Wiley and Sons, Inc, 1990. 768 p.

13. Carlo Viggiani, Alessandro Mandolini, Gianpiero Russo. Piles and Pile Foundations. CRC Press, 2012. 296 p.

14. Gopal Madabhushi, Jonathan Knappett, Stuart Haigh. Design and Pile Foundation in Liquafiable Soils. CRC Press, 2009. 232 p.

15. Arutyunyan N.KH. Nekotoryye voprosy polzuchesti [Some creep issues]. Moscow: Gostekhizdat. 1952. 324 p.

16. Vyalov S.S. Reologicheskiye osnovy mekhaniki gruntov [Rheological foundations of soil mechanics]. Moscow: Vysshaya shkola. 1978. $447 \mathrm{p}$.

17. Rabotnov YU.N. Polzuchest' elementov konstruktsiy [Creep of structural elements]. Moscow: Nauka. 1966. 752 p.

18. Galin L.A. Kontaktnyye zadachi teorii uprugosti i vyazkouprugosti [Contact problems of the theory of elasticity and viscoelasticity]. Moscow: Nauka. 1986. 296 p.

19. Meschyan S.R. Eksperimental'nyye osnovy reologii glinistykh gruntov [Experimental foundations of the rheology of clay soils]. Yerevan: Gitutyun Publishing. 2008. 788 p.

20. Zaretskiy YU.K. Vyazkoplastichnost' gruntov i raschety sooruzheniy [Viscoplasticity of soils and calculations of structures]. Moscow: Stroizdat. 1978. 344 p.

21. Rabotnov YU.N. Kratkovremennaya polzuchest' [Short-term creep]. Moscow: Nauka. 1979. 222 p.

22. Rzhanitsyn A.R. Teoriya polzuchesti [Creep Theory]. Moscow: Stroyizdat. 1968. 419 p.
23. Ter-Martirosyan Z.G., Nguyen Zang Nam. Vzaimodeystviye svay bol'shoy dliny $\mathrm{s}$ neodnorodnym massivom gruntov s uchetom nelineynykh i reologicheskikh svoystv gruntov [Interaction of long piles with a heterogeneous soil mass taking into account the nonlinear and rheological properties of soils] // Vestnik MGSU. 2008. No 2. Pp. 3-14.

24. Ter-Martirosyan Z.G., Ter-Martirosyan A.Z. Mekhanika gruntov [Soil mechanics]. Moscow: Publishing ASV, 2020. 952 p.

25. Bronshteyn I.N.,Semendyayev K.A. Spravochnik po matematike [Handbook of Mathematics]. Moscow: Gostekhizdat. 2009. 608 p.

\section{СПИСОК ЛИТЕРАТУРЫ}

1. Абелев М.Ю., Абелев К.М. Геотехнические исследования площадок строительства, сложенных слабыми водонасыщенными глинистыми грунтами // Геотехника. 2010. №6. C. 30-33.

2. Ибрагимов М.Н., Семкин В.В. Закрепление грунтов инъекцией цементных растворов. Монография, Москва, 2012, 256 с.

3. Бройд И.И. Струйная геотехнология. М.: Ассоц. строит. вузов. 2004. 448 с.

4. Малинин А.Г. Струйная цементация грунтов. URL: https://jet-grouting.info/wpcontent/uploads/2019/02/JET-GROUTING book_Malinin_AG.pdf

5. GarassimoA.Design Procedures for Jet-Grouting // Seminar onjet grouting. Singapore, 1997.

6. Караулов А.М. Практический метод расчета вертикально армированного основания ленточных и отдельностоящих фундаментов транспортных сооружений // Вестник ТГАСУ. 2012. № 2. С. 183-190.

7. Нуждин М.Л. Экспериментальные исследования усиления грунтового основания свайных фундаментов армированием жесткими включениями // Вестник ПНИПУ. Строительство и архитектура. 2019. Т.10, №3. С. 5-15. DOI: 10.15593/2224-9826/2019.3.01.

8. Тер-Мартиросян А.З., Ле Дык Ань, Манукян А.В. Влияние разжижения грунтов 
на расчетную несущую способность свай // Вестник МГСУ.2020. Т. 15. Вып. 5. С. 655-664. DOI: $10.22227 / 1997-0935.2020 .5 .655-664$.

9. Бартоломей А.А., Омельчак И.М., Юшков Б.С. Прогноз осадок свайных фундаментов. М.: Стройиздат. 1994. - 384 с.

10. СП 24.13330.2011 Свайные фундаменты. Актуализированная редакция СНиП 2.02.03-85. M. 2011.

11. Wei Dong Guo. Theory and Practice of Pile Foundations. CRC Press, 2019. - 576 p.

12. Shamsher Prakash, Hari D. Sharma. Pile foundation in engineering practice. John Wiley and Sons, Inc, 1990. - 768 p.

13. Carlo Viggiani, Alessandro Mandolini, Gianpiero Russo. Piles and Pile Foundations. CRC Press, 2012. - 296 p.

14. Gopal Madabhushi, Jonathan Knappett, Stuart Haigh. Design and Pile Foundation in Liquafiable Soils. CRC Press, 2009. - 232 p.

15. Арутюнян H.X. Некоторые вопросы ползучести. М.: Гостехиздат. 1952. - 324 с.

16. Вялов С.С. Реологические основы механики грунтов. М.: Высшая школа. 1978. - 447 с.
17. Работнов Ю.Н. Ползучесть элементов конструкций. М.: Наука. 1966. - 752 с.

18. ГалинЛ.А. Контактныезадачитеории упругости и вязкоупругости. М.: Наука. 1986. -296 с.

19. Месчян С.P. Экспериментальные основы реологии глинистых грунтов. Изд. «Гитутюн». Ереван. 2008. - 788 с.

20. Зарецкий Ю.К. Вязкопластичность грунтов и расчеты сооружений. М.: Строиздат. 1978. - 344 c.

21. Работнов Ю.Н. Кратковременная ползучесть. М.: Наука. 1979. - 222 с.

22. Ржаницын А.Р. Теория ползучести. М.: Стройиздат. 1968. - 419 с.

23. Тер-Мартиросян 3.Г., Нгуен Занг Нам. Взаимодействие свай большой длины с неоднородным массивом грунтов с учетом нелинейных и реологических свойств грунтов // Вестник МГСУ. 2008. №2. - С. 3-14.

24. Тер-Мартиросян 3.Г., Тер-Мартиросян А.3. Механика грунтов. М.: АСВ 2020.952.

25. Бронштейн И.Н., Семендяев К.А. Справочник по математике. М.: Гостехиздат. 2009. 608c.
Zaven G. Ter-Martirosyan - Doctor of Technical Sciences, Professor, Professor of the Department of Soil Mechanics and Geotechnics; National Research Moscow State University of Civil Engineering (NRU MGSU); 129337, Moscow, Yaroslavskoe shosse, 26; SPIN: 9613-8764, ORCID: 0000-0001-9159-6759, Scopus: 35621133900, ResearcherID: Q-8635-2017; ter-martyrosyanzg@mgsu.ru.

Armen Zavenovich Ter-Martirosyan - Doctor of Technical Sciences, Acting Director of the Institute of Construction and Architecture, Head of the Geotechnics Research and Education Center; National Research Moscow State University of Civil Engineering (NRU MGSU); 129337, Moscow, Yaroslavskoe shosse, 26; ORCID: 0000-00018787-826X; RSCI ID 496327; gic-mgsu@mail.ru.

Akuletsky Aleksandr Sergeevich - post-graduate student of the Department of Soil Mechanics and Geotechnics, National Research Moscow State University of Civil Engineering (NRU MGSU); 129337, Moscow, Yaroslavskoe shosse, 26; ORCID: 0000-0001-5752-1120, RSCI ID: 981728; akula.92@inbox.ru.

Завен Григорьевич Тер-Мартиросян - доктор технических наук, профессор, профессор кафедры механики грунтов и геотехники; Национальный исследовательский Московский государственный строительный университет (НИУ МГСУ); 129337, г. Москва, Ярославское шоссе, д. 26; SPIN-код: 9613-8764, ORCID: 0000-00019159-6759, Scopus: 35621133900, ResearcherID: Q-86352017; ter-martyrosyanzg@mgsu.ru.

Армен Завенович Тер-Мартиросян-доктор технических наук, исполняющий обязанности директора Института строительства и архитектуры, руководитель научнообразовательного центра «Геотехника»; Национальный исследовательский Московский государственный строительный университет (НИУ МГСУ); 129337, г. Москва, Ярославское шоссе, д. 26; ORCID: 0000-00018787-826Х; РИНЦ ID 496327;gic-mgsu@mail.ru.

Акулецкий Александр Сергеевич - аспирант кафедры механики грунтов и геотехники, Национальный исследовательский Московский государственный строительный университет (НИУ МГСУ); 129337, г. Москва, Ярославское шоссе, д. 26; ORCID: 0000-0001-5752-1120, РИНЦ ID: 981728; akula.92@inbox.ru. 